\title{
"The prestige of stock exchanges and corporate cash holding in transition economies: a study on Vietnamese listed firms"
}

\author{
Do Thi Thanh Nhan \\ Ngo Minh Vu \\ Pham Ha \\ Drahomíra Pavelková (D https://orcid.org/0000-0003-1399-6129
}

Do Thi Thanh Nhan, Ngo Minh Vu, Pham Ha and Drahomíra Pavelková (2017).

ARTICLE INFO

The prestige of stock exchanges and corporate cash holding in transition economies: a study on Vietnamese listed firms. Investment Management and Financial Innovations, 14(3), 199-209. doi:10.21511/imfi.14(3-1).2017.04

DOI http://dx.doi.org/10.21511/imfi.14(3-1).2017.04

RELEASED ON Wednesday, 08 November 2017

RECEIVED ON

Thursday, 13 July 2017

ACCEPTED ON

Tuesday, 12 September 2017

(oc) EY

LICENSE

This work is licensed under a Creative Commons Attribution 4.0 International License

JOURNAL Investment Management and Financial Innovations"

ISSN PRINT $1810-4967$

ISSN ONLINE $1812-9358$

PUBLISHER

LLC "Consulting Publishing Company "Business Perspectives"

FOUNDER

LLC "Consulting Publishing Company "Business Perspectives"

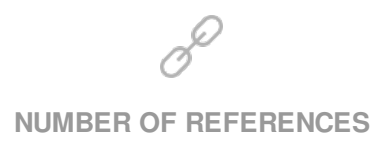

44

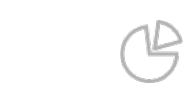

NUMBER OF FIGURES

0

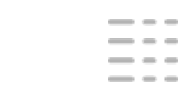

NUMBER OF TABLES

5

(C) The author(s) 2023. This publication is an open access article. 


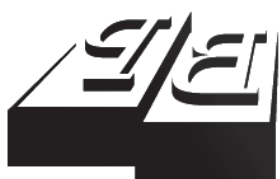

BUSINESS PERSPECTIVES

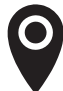

LLC "CPC "Business Perspectives" Hryhorii Skovoroda lane, 10, Sumy, 40022, Ukraine

www.businessperspectives.org

Received on: $13^{\text {th }}$ of July, 2017 Accepted on: $12^{\text {th }}$ of September, 2017

(C) Do Thi Thanh Nhan, Ngo Minh Vu, Pham Ha, Drahomíra Pavelková, 2017

Do Thi Thanh Nhan, M.Sc., Faculty of Management and Economics, Tomas Bata University in Zlín, Czech Republic.

Ngo Minh Vu, M.Sc., Faculty of Management and Economics, Tomas Bata University in Zlín, Czech Republic.

Pham Ha, Dr., Finance and Banking faculty, Hochiminh Open University, Hochiminh city, Vietnam.

Drahomíra Pavelková, Professor, Faculty of Management and Economics, Tomas Bata University in Zlín, Czech Republic.

\section{(ㄷ)(ㄱ)}

This is an Open Access article, distributed under the terms of the Creative Commons Attribution 4.0 International license, which permits unrestricted re-use, distribution, and reproduction in any medium, provided the original work is properly cited.

Do Thi Thanh Nhan (Czech Republic), Ngo Minh Vu (Czech Republic),

Pham Ha (Vietnam), Drahomíra Pavelková (Czech Republic)

\title{
THE PRESTIGE OF STOCK EXCHANGES AND CORPORATE CASH HOLDING IN TRANSITION ECONOMIES: A STUDY ON VIETNAMESE LISTED FIRMS
}

\begin{abstract}
The main purpose is to examine the relationship between corporate cash holding level and the prestige of the stock exchanges. And the other determinants in the listing requirements impact on cash holding level will be indicated. The paper uses a sample of 577 listed firms excluding the financial institutions on the Vietnamese stock exchange over the period 2007-2015. The results show that the listed firms on the stock exchange with higher prestige hold larger amount of cash reserve and vice versa. The study shows that there is a statistically significant connection between cash holding and the listing requirements such as profitability, dividend and information disclosure. The findings have implications on the cash management of listed firms in the stock exchanges with dissimilar prestige.
\end{abstract}

\section{Keywords}

\section{JEL Classification}

\section{INTRODUCTION}

The cash management has many challenges for all kinds of businesses (Ferreira \& Vilela, 2004). The free cash should be invested to earn more profit, while the firms must ensure the appropriate cash to meet the demand in future. Likewise, to manage the appropriate cash reserve level to meet the demand for future is a big question for administrators and researchers. Particularly, if the corporations do not have enough cash to cope with all the situations, these firms may suffer from losing affordability leading to reduction of the firm value (Martínez-Sola et al., 2013). The firms need cash in daily operations as an important source, because they sometimes need money to solve the financial problems immediately (Harford et al., 2008). Nevertheless, holding too much cash causes the increase of carrying cost or opportunity cost, which can reduce the firm value (Dittmar et al., 2003). Furthermore, Harford et al. (2008) conclude that the excess cash will affect the future stock returns and the firm value. In addition, there is also the conflict between the manager and the shareholders in decisions on the level of cash holding because of agency problems (Megginson \& Netter, 2001). Thus, the primary task of the administrator is to find the right cash holding level which has become one of interesting topics for studying. 
The previous studies focus on the other factors which affect the corporate cash holding such as firm size, net working capital, leverage, inventories, growth opportunities, financial distress, cash flow, and dividend payment (Uyar \& Kuzey, 2014; Ogundipe et al., 2012; Megginson et al., 2014). However, this paper examines the relationship between corporate cash holding and the prestige of stock exchange where the firms are listed. In most recent studies, the cash holding level can be explained by three theoretical models: trade-off theory (Myers, 1977), the pecking order theory (Myers \& Majluf, 1984) and agency theory (Jensen, 1986). According to the agency theory, Harford et al. (2008) and Pinkowitz et al. (2006) confirm that the level of corporate governance also impacts on the firm value with different levels of cash holding. Considering corporate governance is one of critical characteristics for the managers and the shareholders of firms, because they will affect the operating activities, as well as the cash management in the corporations (Kusnadi, 2011). Additionally, Turnbull (1997) defines that the internal corporate governance is the compensation policy, the board of directors, and the shareholders, while the external factors are the regulations, the market, government, audit and creditors. As stated in the information above, the stock exchange is considered as one of external corporate governance components which affects the cash management. Moreover, the listing of firms in different stock exchanges has brought a lot benefits such as mitigating the information asymmetry to increase the protection for investor (La Porta et al., 2000). Similarly, Avramov et al. (2006) suggest that the cost of supplying the liquidity will be different on different stock exchanges. Therefore, the listed firms on those stock markets have different opportunities for raising their capital with dissimilar cost, as well as the different stock exchanges have different prestige, which has unlikely impact on the listed firms (Cetorelli \& Peristiani, 2010).

The hypothesis to test listed firms on the higher prestige of the stock exchange has kept higher level of corporate cash holding in Vietnamese context. It is the first study on the interaction between cash holding level and the listed firms on the different reputation of the stock exchange. This paper contributes to the overall interest about investigating the determinants which influence on corporate cash holding level. The most important contribution is to extend the literature in exploring the relationship between the prestige of stock exchange and corporate cash holding in Vietnamese context which represents as an emerging market and transition economy.

The rest of the paper is arranged by defining the model specifications to address the relevant empirical researches, methodology, analyzing the empirical results, and deriving a conclusion based on the findings.

\section{LITERATURE REVIEW}

To know more about the relationship between the prestige of stock market and cash holding, firstly, the study should define the cash holding, as well as the prestige of stock exchange. Cash holding is the ratio between cash and cash equivalent out of total asset which is a tool to measure the importance of cash level in firm value, firm operations and firm performance (Martínez-Sola et al., 2013; Gill \& Shah, 2012; Ogundipe et al., 2012). Secondly, the previous studies suggest that the prestige of stock market is one of factors of external corporate governance (Turnbull, 1997). Particularly, there is the external corporate governance which influences the activities of the firms as raising the capital or manage cash holding level (Jensen, 1993). Harford et al. (2008) state that the managers keep larger cash level when the firms are better protected by better corporate governance.

Subrahmanyam and Titman (1999) confirm the prestige of stock market which influences the firm's operation. The firms are listed or cross-listed on prestigious stock exchange which get higher market performance (Cetorelli \& Peristiani, 2010). Moreover, there is a different impact between the market performance and cash reserve which depend on the industry (Fresard, 2010). Likewise, the cross-listing in high reputation market lead to improve the corporate governance, lower capital cost which is a signal of firm value increase (Benos \& Weisbach, 2004). The growth of firm value lead to better for financial health when they are listed 
in different market with high prestige (Bianconi et al., 2013). Furthermore, the firms are cross-listing in different stock market with their prestige, which can bring more value, as well as ease to raise capital when they need (Lang et al., 2003). Clearly, the firms listed in the higher prestige stock exchange tend to hold less cash level, because they can access the funds easier in the capital market (Opler et al., 1999). To support for it, this study examines the cash holding level of the listed firms on different stock exchanges. The liquidity of listed firm is the ratio between volume of trading and the number of shares in which the trading volume is an important factor to evaluate the prestige of the stock exchange (Sarkissian \& Schill, 2007). Thus, the liquidity is necessary to evaluate the prestige of stock exchange in the model.

Besides, the listed firms have to satisfy all the requirements of the stock market, which are different in every stock exchange, but the main standards focus on the number of shareholders, independent directors and board, profitability, liquidity, information disclosure, compensation committees (Carvajal \& Elliott, 2007). In NYSE, the stock exchange concentrates on some important provisions for listed firms such as the charter capital requirements, profitability and information disclosure (from NYSE listing requirements). Consequently, when the firms fulfill all listing requirements, they are improving their prestige, as well as the creditability, which helps to make it easier for them to raise their capital (Doidge, 2004). Likewise, based on the latest listing requirements in stock exchange under the decision in 2015 from Ministry of Finance in Vietnam, charter capital, profitability (including profit and return on equity) and information disclosure are considered as important requirements which impact on the listed firms, as well as the cash holding level. Firstly, capital requirements influence differently on the firms when they raise capital because of the different reactions of the market and investors (Slovin \& Sushka, 1991). Moreover, the larger amount of charter capital may lead the firm easier to raise their capital, so the firms do not need to hold too much cash. Secondly, Fresard (2010) expresses the connection between profitability of corporation and cash reserve level. In detail, the higher cash holding level can improve the return on equity or the performance of firms (Palazzo,
2012). Nevertheless, Dittmar and Marhrt-Smith (2007) indicate that the market with weak corporate governance do not take all advantages of keeping cash which can cause the decrease in firm profitability. These findings support the listing requirements which can influence the cash holding level. Thirdly, there is the information disclosure requirement which reduces asymmetries of information between issuers and investors, clients and financial intermediaries, and between counterparties (Carvajal \& Elliott, 2007). Reducing the information asymmetry leads to less agency problem in order to decrease the cost for raising capital (Healy \& Palepu, 2003). When the cost of raising capital is cheaper, the firms do not need to keep high level of cash.

Researchers also investigate other factors which impact on the cash holding level. The different ownership structure lead to dissimilar cash reserve level because of the assistances from political connections, the shareholder's support or their management skills in order to take advantages of keeping cash in operating the businesses (Yu, 2013). The different ownership structure can cause the agency cost due to the agency problems between shareholders and managers (agency theory by Jensen, 1986). In other words, being stateowned may cause the poor corporate governance mechanisms and agency problems which can impact negatively on cash holding level (Megginson et al., 2014). Besides, Le and Buck (2011), Le and Chizema (2011) find out the positive connection between cash holding level and state ownership, while Borisova et al. (2012) state the negative association between state-owned and cash holding. Institutional ownership besides state-owned affects the capital management, as well as liquidity of firms owing to institution's experience (Lehmann \& Weigand, 2000). In particular, the institutions tend to keep more money, because they have more chances in investment opportunities and more professional investors than the individual investors (McConnell \& Servaes, 1990).

Referring to the dividend factor, the dividend policy has influence on the cash holding plan. In detail, the higher dividend impacts negatively on cash reserve, because the firms can cut the dividend when they need money (Ferreira \& Vilela, 2004). This result is similar to the pecking order 
theory; the firms use the internal sources before using the external source to reduce the cost of borrowing. Besides, the larger firms easily get external capital with cheaper cost, so they do not need to hold too much cash (Ferreira \& Vilela, 2004; Uyar \& Cemil, 2014; Saddour, 2006). Nevertheless, Megginson and Wei (2010) show that the larger firm should keep high level of cash to take all advantages of holding cash to invest in all the opportunities. Turning to the capital expenditure, Uyar and Kuzey (2014) show that capital expenditure is one of factors impacting negatively on cash holding level. Opler et al. (1999) finds a negative association between cash and capital expenditure. The growth in capital expenditure decreases the cash holding level (Dittmar et al., 2003; Chen, 2008).

\section{METHODOLOGY AND SELECTED VARIABLES}

The market capitalization, the number of initial public offerings (IPO) and trading volume are the main elements to recognize the prestige of the stock exchange (Pagano et al., 2002; Zingales, 2006; Sarkissian \& Schill, 2007). Cetorelli and Peristiani $(2009,2010)$ indicate the method to measure the prestige for stock exchanges. IPO activities are chosen in the measurement for the prestige of stock exchanges which confirm that the United States market has the highest ranking. In the paper of Cetorelli and Peristiani in 2010, the U.S. market maintained high prestige owing to market size, trading volume, IPO activities and the destination of listing firms. Based on the indicators, the paper evaluates the prestige for Hochiminh stock exchange and Hanoi stock exchange as in the table below.

As we can see, the market capitalization, value of listing, trading volume, the number of shares and IPO activities in HOSE are higher than in
HNX. Based on the information above, we can see that the stock exchange in Hochiminh (HOSE) has higher prestige in comparison with stock exchange in Hanoi (HNX) due to these indicators above (Cetorelli \& Peristiani, 2009, 2010). In order to test the hypothesis, as well as to build the appropriate model, it is necessary to carry out a descriptive analysis of the variables. Moreover, the paper presents the data that were used. The regression method was used to examine the hypothesis.

\subsection{Data}

The data are from financial statements of listed firms on two largest stock exchange in Vietnam, Hochiminh Stock Exchange (HOSE) and Hanoi Stock Exchange (HNX) from 2007 to 2015. In 2007, many corporations were listed on the stock exchange with a lot of preferential exemptions which boosted the market. During that time, the stock exchange in Vietnam was developing very fast and the economy was also experiencing an unstable situation as the interest rate increased. Therefore, listed companies had an incentive to keep more cash in order to obtain all the opportunities, as well as to avoid the high cost of borrowing. Due to that, researchers of this study selected Vietnam stock exchange for the period 2007-2015. This research collected a sample of 577 listed firms (excluding financial institutions) on two stock exchanges (HOSE and HASTC). The data include financial information at the end of the year from financial reports including income statements, balance sheets, explanations for the financial statement, and annual reports.

\subsection{Variables}

CASH is cash holding as a dependent variable in this paper. The cash holding has been defined as cash and cash equivalent which is divided by total

Table 1. Hochiminh and Hanoi stock exchanges in Vietnam

Source: HOSE and HNX on May 15, 2017.

\begin{tabular}{l|c|c}
\multicolumn{1}{c}{ Criteria } & HOSE & HNX \\
\hline Market capitalization & 74,270 mil USD & 7,383 USD \\
Value of listing & 23,408 bil USD & 4,977 bil USD \\
Trading volume & 159,098 mil USD & 26,984 mil USD \\
The number of shares of IPO & $52,127,862,030$ shares & $11,296,889,937$ shares \\
\hline
\end{tabular}


assets (Martínez-Sola et al., 2013; Ozkan \& Ozkan, 2004; Harford et al., 2008).

LISTED is a proxy of the prestige of the stock exchange. This variable is employed for the first time in order to test the prestige which can influence the cash holding. In Vietnamese stock exchange, there are two stock exchanges which have different listing standards. Furthermore, the paper has already confirmed that HOSE has higher prestige than HNX. The LISTED variable uses as a proxy to find out whether the prestige of stock exchange can impact on the cash reserve level or not.

STATE is represented as the percentage of a total number of shares that the government owns which influences the cash reserve level (Megginson et al., 2014; Borisova et al., 2012).

INSTITUTIONAL is the proportion of shares owned by the institutions. Lehmann and Weigand (2000) argue that the companies have institutional ownership with more experience in the capital market, as well as managing the liquidity. The firms with higher institution-owned can obtain better opportunities when they keep more liquidity assets.

SIZE is the logarithm of total assets. Moreover, smaller firms have higher cash level which is in the line with the trade-off theory (Ferreira \& Vilela, 2004).

PROFIT is stated as a proxy variable. It indicates if the company gets profit or not in the year. If the company gets more profit from operating activities which create large cash flow, the firm can reduce the cash reserve (Kim et al., 1998). And the company decreases to mobilize capital when it has higher profit (Opler et al., 1999; Ferreira \& Vilela, 2004). Nevertheless, some companies intend to keep more cash, as they can get more profit in growing periods (Megginson \& Wei, 2010; Ogundipe et al., 2012). In this paper, it is used as a dummy variable to meet one of important requirements for listed firms.

DIV variable is the payment that the firm pays out in a given year. In addition, Opler et al. (1999) and Meggison et al. (2014) point out the association between cash and dividend payment, so we expect the same direction in Vietnamese corporations. The dividend represents one of vital conditions for listed firms.

LIQUIDITY is a proxy variable for turnover rate which is measured by the trading volume and the outstanding number of shares. This ratio has a vital function in explaining the relation between liquidity and stock return (Datar et al., 1998). Furthermore, the stock return impacts on the capital investment, as well as the capacity for raising funds of firms (Titman et al., 2004). This variable is important for the listed firms to be aware of the ability in raising funds in the stock market.

MB is a dummy variable for information disclosure in the stock market. This variable informs if the listed firms are following the listing requirement for announcing the information in the right time or not. In particularly, the information disclosure affects strongly on the performance of firms, as well as the cost of capital when the listed firms want to raise their capital (Lambert et al., 2007).

\section{Table 2. Summary of all variables}

\begin{tabular}{l|l}
\hline \multicolumn{1}{c}{ Variables } & \multicolumn{1}{c}{ Definitions } \\
\hline CASH & $\begin{array}{l}\text { The ratio of cash and cash equivalents to total assets } \\
\text { n dumber } 2 \text { for the listed firms that were cancelled }\end{array}$ \\
LISTED & State is the fraction of shares owned by the state \\
STATE & Institutional is the fraction of shares owned by the institutions \\
INSTITUTIONAL & A dummy variable with a value of 1 if the corporations have profit and 0 otherwise \\
\hline PROFIT & Size is the logarithm of total assets \\
SIZE & Dividend is the payment for the shareholders in cash \\
DIV & Equal to the trading volume and the outstanding number of shares \\
\hdashline LIQUIDITY & Return on equity is the ratio of equity by the net profit \\
ROE & 1 means the listed firms announce the information on time according to the regulations and otherwise is 0 \\
\hline MB &
\end{tabular}


CAPEX is the capital expenditure which is the fund of firms to upgrade the physical assets. Opler et al. (1999) state that the determinants such as capital expenditure affect the cash holding level in the firms. Similarly, Lee and Lee (2009) believe that the capital expenditure has a connection with the cash reserve and we expect the same result in this paper.

$\mathrm{ROE}$ is the ratio between net profit and equity of the firm. Abushammala and Jamalludin (2014) express that the corporation holds more cash which can be managed to solve problems in the business, while less cash holding may cause some troubles in earning profit. $\mathrm{ROE}$ is one of important requirements for listed firms.

\subsection{Model}

To estimate the right amount of cash holding lev$\mathrm{el}$, the previous papers focus on the internal factors of the firm (Meggison et al., 2014; Ferreira \& Vilela, 2004). In this case, we would like to test the prestige of stock exchange which impacts on the cash reserve level. Besides, two stock exchanges have some main requirements for listed firms, as well as the other factors which can influence on cash reserve level. Hence, there could be some variables which are present in both the cash holding and the listing requirements. These elements make the estimated results unreliable. To avoid this, we would like to use the IV process in which the listing requirements are employed and the cash holding is also determined by some of those conditions. The model used is presented in equation 1 below:

$$
\operatorname{Cash}_{i t}=\beta_{0}+\beta_{1} \text { listed }+\beta_{k} X_{k}+\varepsilon_{1}
$$

In the model 1, according to Martinez-Sola et al. (2013), cash is a dependent variable and is the quotient of cash and cash equivalent out of total assets. According to Al-Najjar and Clark (2016), Ferreira and Vilela (2004), the stock exchange prestige is an important factor which impacts on liquidity management. Besides, the listed conditions on HOSE and HNX have different standards or regulations which the listed firms should follow. In this model, we consider cash holding as the dependent variable and the prestige of stock exchanges as one of independent variables, which leads to employing the IV model.

\section{EMPIRICAL RESULTS AND DISCUSSION}

\subsection{Descriptive statistics}

The Table 3 represents the summary of descriptive statistics of all variables are used in the models over the period 2007-2015. It provides a general view of all data.

Table 3. Sample statistics

\begin{tabular}{|c|c|c|c|c|c|}
\hline Variables & Obs. & Mean & Std. dev. & Min & Max \\
\hline $\mathrm{CASH}$ & 3841 & 0.101 & 0.108 & 0.000 & 0.669 \\
\hline STATE & 3841 & 24.41 & 23.42 & 0.000 & 79.91 \\
\hline INSTITUTIONAL & 3841 & 8.143 & 12.30 & 0.000 & 49.01 \\
\hline LISTED & 3841 & 0.495 & 0.528 & 0.000 & 2.000 \\
\hline PROFIT & 3841 & 9.816 & 1.818 & 2.326 & 16.46 \\
\hline SIZE & 3841 & 5.080 & 0.570 & 3.698 & 7.277 \\
\hline LIQUIDITY & 3841 & 0.004 & 0.007 & 0.000 & 0.209 \\
\hline ROE & 3841 & 0.139 & 0.104 & 0.000 & 0.601 \\
\hline DIV & 3841 & 0.771 & 0.419 & 0.000 & 1.000 \\
\hline $\mathrm{MB}$ & 3841 & 0.972 & 0.163 & 0.000 & 1.000 \\
\hline
\end{tabular}

Notes: CASH is a cash equivalent out of total asset; LISTED is a dummy variable with a value of 0 if the firms are listed in HOSE, number 1 for listed firms in HNX and number 2 for the listed firms that were cancelled; STATE is the fraction of shares owned by the state; INSTITUTIONAL is the fraction of shares owned by the institutions; PROFIT is a dummy variable with a value of 1 if the corporations have profit and 0 otherwise; SIZE is the logarithm of total assets; DIV is the payment for the shareholders in cash; LIQUIDITY is equal to the trading volume and the outstanding number of shares; ROE is the ratio of equity by the net profit; MB is a dummy variable: 1 means the listed firms announce the information on time according to the regulations and otherwise is 0 . 
The above table shows the description of the data, we can see that the cash to total assets of listed firms in Vietnam with the average value is around $10 \%$ which is similar in previous papers (Opler et al., 1999; Ozkan \& Ozkan, 2004). However, this ratio is higher than the average cash holding in Spain with $6.57 \%$ (Teruel \& Solano, 2008), in United State with 7.9\% (Martínez-Sola et al., 2013), in Canada with $3.87 \%$ (Gill \& Shah, 2010), in Nigeria with 7.18\% (Ogundipe et al., 2012). As the cash holding level in Vietnam stock exchange is higher in comparison with others due to the fact that the stock market had the bubble bursting during the global financial crisis in 2008. And borrowing money from the bank has become more difficult issue. Under these circumstances, the corporations should have strategies for keeping cash reserves effectively.

\subsection{Regression}

Since there are some common characteristics that have an effect on cash, they also have influence on the listed conditions of firms, so that will be biased if we estimate the main model. To avoid this, as mentioned above, we employ three-stage leastsquares regression to analyze the impact of the prestige of stock exchange on the cash reserve level by using dummy variable LISTED. The results of model are given in Table 4 below.
The result shows that the higher prestige of the stock exchange leads the listed firms to hold higher level of cash reserve. This finding rejects the hypothesis and the LISTED variable is not as expected. According to the literature review, the higher prestige of listing conditions in HOSE leads to lower cash reserve of the listed firms owing to the higher reputation which is easier for the firms to raise their capital with lower cost (Opler et al., 1999). However, the results show that cash holding level has a positive connection with the listed firms in HOSE. In particular, the listed firms in HOSE keep more cash than the listed firms in HNX which can be explained as follows. Likewise, the listed firms on higher prestige stock exchange have attracted more investment (Nahata, 2008).

Additionally, the larger size of firms which bring more investment opportunities for the firms should keep more cash in order to take all the advantages rather than using the external source. This outcome is similar to finding of Megginson and Wei (2010). In particular, the listed firms on HOSE has larger size than listed firms in HNX. Therefore, the listed firms in HOSE reserve higher cash level in comparison with the listed firms in HNX, because they want to obtain all opportunities in order to meet the needs in their business. Furthermore, the lending and borrowing interest rates rose to $18 \%$ per year and the

Table 4. Impact of the prestige of stock exchanges on the cash holding level

\begin{tabular}{|c|c|c|c|c|c|c|}
\hline CASH & Coef. & Std. err. & $\mathbf{z}$ & $\mathbf{P}>\mathbf{Z}$ & \multicolumn{2}{|c|}{ [95\% Conf. Interval] } \\
\hline STATE & 0.000 & 0.000 & 5.42 & 0.000 & .0002 & .0005 \\
\hline LISTED & -0.007 & 0.035 & -2.05 & 0.040 & -.0144 & -.0003 \\
\hline INSTITUTIONAL & 0.000 & 0.000 & 5.72 & 0.000 & .0005 & .0011 \\
\hline PROFIT & 0.014 & 0.001 & 1.10 & 0.273 & -.0011 & .0039 \\
\hline LIQUIDITY & -0.588 & 0.231 & -2.54 & 0.001 & -1.042 & -.1341 \\
\hline $\mathrm{ROE}$ & 0.240 & 0.019 & 12.34 & 0.000 & .2026 & .2792 \\
\hline $\mathrm{MB}$ & 0.011 & 0.010 & 1.14 & 0.255 & -.0084 & .0318 \\
\hline CONS & 0.031 & 0.014 & 2.21 & 0.027 & .0003 & .0599 \\
\hline \multicolumn{7}{|c|}{ LISTED } \\
\hline SIZE & 0.355 & 0.017 & 20.49 & 0.000 & 0.321 & 0.389 \\
\hline PROFIT & 0.040 & 0.005 & 7.350 & 0.000 & 0.029 & 0.050 \\
\hline CONS & -1.705 & 0.067 & -25.47 & 0.000 & -1.837 & -1.574 \\
\hline Equation & Obs & Parms & RMSE & $\mathbf{R} 2$ & chi2 & P-value \\
\hline $\mathrm{CASH}$ & 3841 & 7 & 0.103 & 0.0901 & 388.34 & 0.000 \\
\hline LISTED & 3841 & 2 & 0.462 & 0.235 & 1186.2 & 0.000 \\
\hline
\end{tabular}

Notes: CASH is equal cash and cash equivalent out of total asset; LISTED is a dummy variable with a value of 0 if the firms are listed in HOSE, number 1 for listed firms in HNX and number 2 for the listed firms that were cancelled; STATE is the fraction of shares owned by the state; INSTITUTIONAL is the fraction of shares owned by the institutions; PROFIT is a dummy variable with a value of 1 if the corporations have profit and 0 otherwise; SIZE is the logarithm of total assets; LIQUIDITY is equal to the trading volume and the outstanding number of shares; ROE is the ratio of equity by the net profit; MB is a dummy variable: 1 means the listed firms announce the information on time according to the regulations and otherwise is 0 . 
lending policies of banks were tightened. Therefore, borrowing money from the bank has become more difficult issue. Furthermore, the companies need capital, but the markets lack capital and money due to the fact that the mobilization channels have been limited. Under these circumstances, the corporations should have strategies for capital and cash reserves effectively. As a result, the listed firms can take part in the new investments chance which do not have to take risk or higher borrowing cost from external sources. This is similar with from pecking order and free cash flow theory and it is consistent with results from Ferreira and Vilela (2004), Uyar and Kuzey (2014). Equally, the listed corporations in Vietnam tend to keep more cash in order to avoid the high cost of external financing which is in the line with these finding.

One of other interesting finding is that the higher level of state ownership leads to hoard larger cash reserve in the listed firms. This is consistent with previous studies (Le \& Buck, 2011; Le \& Chizema, 2011). Moreover, the listed companies have a higher level of state ownership hold more cash reserve to prevent the risk or extra cost in the future which is in line with $\mathrm{Yu}$ (2013). Besides, the institutional ownership variable is also positive and significant with cash holding. This means that the companies increase the amount of cash reserve when the proportion of institutional ownership is higher. It is reasonable, because the institutions offer benefits from managerial skills and experience (McConnell \& Servaes, 1990). Thus, the institution may have more investment opportunities base on their connections and experiences. Next, the information disclosure is insignificant with the cash holding level, as the information disclosure is not important factor which have an influence on the cash reserve.

The experimental results provide the profit and return on equity which are the factors to determine the cash holding level. In detail, the profit is positively significant to the cash holding level which is used as the tool variable. This finding indicates that the listed firms with higher profit keep more cash in order to obtain more opportunities in the growing period of the economy. This is similar to the results from Megginson and Wei (2010). And return on equity is significantly and positively connected with the cash holding level. The firm keep more cash in order to take all advantages in the investment which is similar with results of the previous papers (Megginson \& Wei, 2010; Ogundipe et al., 2012). Besides, liquidity of listed shares in the stock exchange negatively im-

Table 5. Robust check for the impact of the prestige of stock exchanges on the cash holding level

\begin{tabular}{|c|c|c|c|c|c|c|}
\hline CASH & Coef. & Std. err. & $\mathbf{z}$ & $\mathbf{P}>\mathbf{Z}$ & \multicolumn{2}{|c|}{ [95\% Conf. Interval] } \\
\hline STATE & 0.000 & 0.000 & 4.34 & 0.000 & .0001 & .0004 \\
\hline LISTED & -0.006 & 0.035 & -1.87 & 0.061 & -.0137 & -.0003 \\
\hline INSTITUTIONAL & 0.000 & 0.000 & 5.49 & 0.000 & .0005 & .0011 \\
\hline PROFIT & 0.000 & 0.001 & 0.56 & 0.574 & -.0018 & .0032 \\
\hline LIQUIDITY & -0.476 & 0.232 & -2.05 & 0.040 & -.9318 & -.0217 \\
\hline ROE & 0.235 & 0.019 & 12.0 & 0.000 & .1967 & .0280 \\
\hline DIV & 0.019 & 0.004 & 4.78 & 0.000 & .0117 & .2733 \\
\hline $\mathrm{MB}$ & 0.014 & 0.010 & 1.39 & 0.166 & -.0005 & .0342 \\
\hline CONS & 0.022 & 0.014 & 1.57 & 0.117 & -.0056 & .0509 \\
\hline \multicolumn{7}{|c|}{ LISTED } \\
\hline SIZE & 0.3554 & 0.017 & 20.62 & 0.000 & .3216 & .3892 \\
\hline PROFIT & 0.0382 & 0.045 & 7.06 & 0.000 & .0276 & .0488 \\
\hline $\mathrm{MB}$ & 0.3369 & 0.045 & 7.43 & 0.000 & .0248 & .4257 \\
\hline CONS & -2.0130 & .078 & -25.65 & 0.000 & -2.167 & -1.859 \\
\hline Equation & Obs. & Parms & RMSE & $\mathbf{R} 2$ & chi2 & P-value \\
\hline $\mathrm{CASH}$ & 3841 & 8 & 0.1030 & 0.095 & 413.0 & 0.000 \\
\hline LISTED & 3841 & 3 & 0.4592 & 0.245 & 1256.9 & 0.000 \\
\hline
\end{tabular}

Notes: CASH is equal cash and cash equivalent out of total asset; LISTED is a dummy variable with a value of 0 if the firms are listed in HOSE, number 1 for listed firms in HNX and number 2 for the listed firms that were cancelled; STATE is the fraction of shares owned by the state; INSTITUTIONAL is the fraction of shares owned by the institutions; PROFIT is a dummy variable with a value of 1 if the corporations have profit and 0 otherwise; SIZE is the logarithm of total assets; LIQUIDITY is equal to the trading volume and the outstanding number of shares; MB is a dummy variable: 1 means the listed firms announce the information on time according to the regulations and otherwise is 0; SIZE is the logarithm of total assets; DIV is the payment for the shareholders in cash. 
pacts cash holding which is consistent with results from Opler et al. (1999). This finding posits that the listed firms can keep less cash when the liquidity of the share on the stock exchange is higher owing to the marketability of the share.

\subsection{Robustness checks}

We apply the robustness testing to check how stable the model is, as well as how stable the change in results is. In this part, we modify DIV and MB as a tool variable in order to test stability of the results.
The result points out that there is no change of signs in all variables. The variables STATE, INSTITUTIONAL, ROE and PROFIT are positively related to the cash holding level of listed firms on the stock exchange. These results in the robust test which is the same with the first one. The robust test confirms that the firms listed on the higher prestige stock exchange keep higher cash level. With the regression result from the modification of the dependent variables as dividend, the results of main variable LISTED do not change which indicates strength or stability of the model.

\section{CONCLUSION}

The paper explores the determinants that have an impact on stock exchange in transition economies. In detail, the study investigates that there is a relationship between cash holding level and the prestige of Vietnamese stock exchange from 2007 to 2015. For the analysis, the paper uses IV modeling to eliminate the endogeneity problem in the model. The results indicate that the higher prestige of stock exchange is linked with the higher level of cash holding. Conversely, the listed corporations in lower prestige market will hold less cash level. This finding could be a reference for listed firm to keep the right amount of cash in order to improve their profit, as well as firm value.

Reference to the variation in the variables are listing requirements as ROE and information disclosure which are positively connected with the cash holding level. The finding consistent with the prestige of stock exchange, listing requirements and cash reserve level. In particular, the higher prestige of stock exchange has more requirements keep more cash in order to get all investment opportunities. Moreover, they are listed in higher prestige stock exchange which improve their performance, as well as the higher chance for investment. Therefore, the firms are listed in different stock exchange that consider to keep the right amount of cash reserve.

Besides, the study finds out that the state ownership and institutional ownership interact in the same way with cash holding due to the poor corporate governance and agency problems. Furthermore, the firms with state ownership or institutional ownership can take advantages of their political connections to get more investment opportunities. Thus, they may keep more cash to get all the opportunities, as well as prevent the risk of shortage funds. The dividend has the same trend with the cash holding level, the listed firms need to keep more cash in order to pay more dividend. Next, the liquidity of market negatively correlates with the cash holding level. In this case, the higher liquidity of the listed firms that do not need to keep money due to the fact is that the firms can easily sell the shares to gain capital. Besides, the firms paying more for the board lead to reduced amount of cash holding. These investigations for the listed corporations in Vietnam should be considered as a vital reference to keep suitable the amount of cash which improves the firm performance.

\section{ACKNOWLEDGMENT}

The authors would like to thank the Internal Grant Agency of FaME for providing financial support to carry out this research. Funding was extended through: TBU No. IGA/FaME/2017/004 - The Relationship between Concentration Ownership and Financial Reporting Quality. 


\section{REFERENCES}

1. Abushammala, S. N., \& Sulaiman, J. (2014). Cash holdings and corporate profitability: Some evidences form Jordan. International Journal of Innovation and Applied Studies, 8(3), 898. Retrieved from https://search. proquest.com/docview/161534945 5 ? accountid $=15518$

2. Al-Najjar, B., \& Clark, E. (2017). Corporate governance and cash holdings in MENA: Evidence from internal and external governance practices. Research in International Business and Finance, 39, 1-12. https://doi.org/10.1016/j.ribaf.2016.07.030

3. Avramov, D., Chordia, T., \& Goyal, A. (2006). Liquidity and autocorrelations in individual stock returns. The Journal of Finance, 61(5), 2365-2394. Retrieved from http://onlinelibrary. wiley.com/doi/10.1111/j.15406261.2006.01060.x/abstract

4. Benos, E., \& Weisbach, M. S. (2004). Private benefits and cross-listings in the united states. Emerging Markets Review, 5(2), 217-240. https://doi.org/10.1016/j. ememar.2004.01.002

5. Bianconi, M., Chen, R., \& Yoshino, J. A. (2013). Firm value, the Sarbanes-Oxley Act and crosslisting in the U.S., Germany and Hong Kong destinations. The North American Journal of Economics and Finance, 24, 25-44. https://doi. org/10.1016/j.najef.2012.07.002

6. Chizema, A., \& Le, T. (2011). State ownership and firm performance: Evidence from the chinese listed firms. Organizations and Markets in Emerging Economies, 2(2), 72-90. Retrieved from http://econpapers. repec.org/article/vulomefvu/v_3a2 _3ay_3a2011_3ai_3a2_3aid_3a119. htm

7. Datar, V. T., Y. Naik, N., \& Radcliffe, R. (1998). Liquidity and stock returns: An alternative test. Journal of Financial Markets, 1(2), 203-219. https://doi.org/10.1016/S13864181(97)00004-9

8. Dittmar, A., \& Mahrt-Smith, J. (2007). Corporate governance and the value of cash holdings. Journal of Financial Economics, 83(3), 599634. Retrieved from http://EconPapers.repec.org/RePEc:eee:jfinec:v:8 3:y:2007:i:3:p:599-634

9. Dittmar, A., Mahrt-Smith, J., \& Servaes, H. (2003). International corporate governance and corporate cash holdings. Journal of Financial and Quantitative Analysis, 38(01), 111-133. Retrieved from http://www.jstor. org/stable/4126766

10. Doidge, C. (2004). U. S. crosslistings and the private benefits of control: Evidence from dualclass firms. Journal of Financial Economics, 72(3), 519-553. https://doi.org/10.1016/S0304405X(03)00208-3

11. Elliott, M. J. A., \& Carvajal, A. (2007). Strengths and weaknesses in securities market regulation: A global analysis (International Monetary Fund. IMF Working Paper, 07/259). Retrieved from Carvajal, Ana and Elliott, Jennifer E., Strengths and Weaknesses in Securities Market Regulation: A Global Analysis (November 2007). (IMF Working Papers, 1-49, 2007). Retrieved from https://ssrn. com/abstract $=1030688$

12. Ferreira, M. A., \& Vilela, A. S. (2004). Why do firms hold cash? Evidence from EMU countries. European Financial Management, 10(2), 295-319. https://doi.org/10.1111/j.13547798.2004.00251.x

13. García-Teruel, P. J., \& Martínez Solano, P. (2008). On the determinants of SME cash holdings: Evidence from spain. Journal of Business Finance \& Accounting, 35(1-2), 127-149. https://doi.org/10.1111/j.14685957.2007.02022.x

14. Gill, A., \& Shah, C. (2012). Determinants of corporate cash holdings: Evidence from canada. International Journal of Economics and Finance, 4(1), 70. http://dx.doi. org/10.5539/ijef.v4n1p70

15. Healy, P. M., \& Palepu, K. G. (2001). Information asymmetry, corporate disclosure, and the capital markets: A review of the empirical disclosure literature. Journal of Accounting and Economics, 31(1-3), 405-440. https://doi.org/10.1016/ S0165-4101(01)00018-0

16. Jensen, M. C. (1986). Agency costs of free cash flow, corporate finance, and takeovers. The American Economic Review, 76(2), 323-329. Retrieved from http://www.jstor. org/stable/1818789

17. Jensen, M. C. (1993). The modern industrial revolution, exit, and the failure of internal control systems. The Journal of Finance, 48(3), 831-880. https:// doi.org/10.1111/j.1540-6261.1993. tb04022.x

18. Kusnadi, Y. (2011). Do corporate governance mechanisms matter for cash holdings and firm value? Pacific-Basin Finance Journal, 19(5), 554-570. https://doi.org/10.1016/j. pacfin.2011.04.002

19. La Porta, R., Lopez-de-Silanes, F., Shleifer, A., \& Vishny, R. (2000). Investor protection and corporate governance. Journal of Financial Economics, 58(1), 3-27. https://doi.org/10.1016/S0304405X(00)00065-9

20. Lambert, R., Leuz, C., \& Verrecchia, R. E. (2007). Accounting information, disclosure, and the cost of capital. Journal of Accounting Research, 45(2), 385420. https://doi.org/10.1111/j.1475679X.2007.00238.x

21. Lang, M. H., Lins, K. V., \& Miller, D. P. (2003). ADRs, analysts, and accuracy: Does cross listing in the united states improve a firm's information environment and increase market value? Journal of Accounting Research, 41(2), 317345. https://doi.org/10.1111/1475679X.00106

22. Le, T. V., \& Buck, T. (2011). State ownership and listed firm performance: A universally negative governance relationship? Journal of Management \& Governance, 15(2), 227-248. Retrieved from http://hdl.handle. net/10.1007/s10997-009-9098-5 
23. Lee, K., \& Lee, C. (2009). Cash holdings, corporate governance structure and firm valuation. Review of Pacific Basin Financial Markets and Policies, 12(03), 475-508. https://doi.org/10.1142/ S021909150900171X

24. Lehmann, E., \& Weigand, J. (2000) Does the governed corporation perform better? governance structures and corporate performance in Germany. European Finance Review, 4(2), 157-195. http://dx.doi.org/10.2139/ ssrn. 275834

25. Martínez-Sola, C., García-Teruel, P. J., \& Martínez-Solano, P. (2013). Corporate cash holding and firm value. Applied Economics, 45(2), 161-170. http://dx.doi.org/10.1080/ 00036846.2011 .595696

26. McConnell, J. J., \& Servaes, H. (1990). Additional evidence on equity ownership and corporate value. Journal of Financial Economics, 27(2), 595-612. https://doi.org/10.1016/0304405X(90)90069-C

27. Megginson, W. L., \& Netter, J. M. (2001). From state to market: A survey of empirical studies on privatization. Journal of Economic Literature, 39(2), 321-389. Retrieved from http://www.jstor. org/stable/2698243

28. Megginson, W. L., Ullah, B., \& Wei, Z. (2014). State ownership, soft-budget constraints, and cash holdings: Evidence from China's privatized firms. Journal of Banking \& Finance, 48, 276-291. https://doi. org/10.1016/j.jbankfin.2014.06.011

29. Myers, S. C., \& Majluf, N. S. (1984). Corporate financing and investment decisions when firms have information that investors do not have. Journal of Financial Economics, 13(2), 187-221. https://doi.org/10.1016/0304 405X(84)90023-0
30. Myers, S. C. (1977). Determinants of corporate borrowing. Journal of financial economics, 5(2), 147-175. Retrieved from http://EconPapers. repec.org/RePEc:eee:jinec:v:5:y:19 77:i:2:p:147-175

31. Nahata, R. (2008). Venture capital reputation and investment performance. Journal of Financial Economics, 90(2), 127-151. https://doi.org/10.1016/j.jineco.2007.11.008

32. Ogundipe, L. O., Ogundipe, S. E., \& Ajao, S. K. (2012). Cash holding and firm characteristics: Evidence from nigerian emerging market. Journal of Business, Economics, 1(2), 45-58. Retrieved from http://dergipark.ulakbim. gov.tr/jbef/article/download/ 5000075829/5000070130

33. Opler, T., Pinkowitz, L., Stulz, R., \& Williamson, R. (1999). The determinants and implications of corporate cash holdings. Journal of Financial Economics, 52(1), 3-46. https://doi.org/10.1016/S0304405X(99)00003-3

34. Ozkan, A., \& Ozkan, N. (2004). Corporate cash holdings: An empirical investigation of UK companies. Journal of Banking \& Finance, 28(9), 2103-2134. https://doi.org/10.1016/j.jbankfin.2003.08.003

35. Palazzo, B. (2012). Cash holdings, risk, and expected returns. Journal of Financial Economics, 104(1), 162-185. https://doi.org/10.1016/j. jineco.2011.12.009

36. Pinkowitz, L., Stulz, R., \& Williamson, R. (2006). Does the contribution of corporate cash holdings and dividends to firm value depend on governance? A cross-country analysis. The Journal of Finance, 61(6), 2725-2751. https://doi.org/10.1111/j.15406261.2006.01003.x
37. Sarkissian, S., \& Schill, M. J. (2007). Are there permanent valuation gains to overseas listing? Review of Financial Studies, 22(1), 371412. http://dx.doi.org/10.2139/ ssrn. 395140

38. Slovin, M. B., Sushka, M. E., \& Polonchek, J. A. (1991). The information content of multiple seasoned common stock offerings by bank holding companies. Journal of Banking \& Finance, 15(3), 633-646. https://doi. org/10.1016/0378-4266(91)90089-5

39. Subrahmanyam, A., \& Titman, S. (1999). The going-public decision and the development of financial markets. The Journal of Finance, 54(3), 1045-1082. https:// doi.org/10.1111/0022-1082.00136

40. Titman, S., Wei, K. J., \& Xie, F. (2004). Capital investments and stock returns. Journal of Financial and Quantitative Analysis, 39(04), 677-700. Retrieved from http:// www.jstor.org/stable/30031881

41. Turnbull, S. (1997). Corporate governance: Its scope, concerns and theories. Corporate Governance: An International Review, 5(4), 180-205. https://doi.org/10.1111/14678683.00061

42. Uyar, A., \& Kuzey, C. (2014). Determinants of corporate cash holdings: Evidence from the emerging market of turkey. Applied Economics, 46(9), 1035-1048. http:// dx.doi.org/10.1080/00036846.201 3.866203

43. Xu, N., Chen, Q., Xu, Y., \& Chan, K. C. (2016). Political uncertainty and cash holdings: Evidence from china. Journal of Corporate Finance, 40, 276-295. https://doi. org/10.1016/j.jcorpfin.2016.08.007

44. Yu, M. (2013). State ownership and firm performance: Empirical evidence from Chinese listed companies. China Journal of Accounting Research, 6(2), 75-87. https://doi.org/10.1016/j. cjar.2013.03.003 